か は

わき

らわ

ず、め

最 日

近 常

で 的

はな

社 象

会 で

学あ

にり

预重

七重

そな

れ 社

が 会

正 関

面 係

切 の

ว 一

て

り

ある

たは言げ

ᄂ、元 ら

、歴なれ

そ史いる

の的 ${ }^{\circ}$

重に研亡

要近究は

性代者

は以のと

現降関ん

社個はな゙

会人とい

におうし

いびろま

て社うた

女会 と

決構多体

乙造、采

七社的

失重会に

わ要関展

れな係開

て意とされ

なをして

小むてい

つのる

て競を

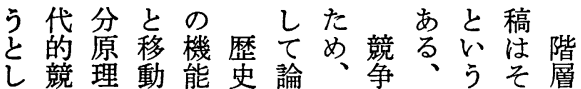

た争ととは的及空はそょの構

ものしいまにさ気ごのり一造

の特てうすはれのく意もつの

で質競型ま、た如あ味、で研

あを争です競がくりで現あ究

る資を研増争、当子、代るに

源位究大は現然れ意社人は

の置肪し近在のた図会員大

稀ゔ蓄て代でこ皇会配き

少け積い社はとごし種分

性、さる会部とくて危分

で個れ。の分し二はの論け

は人てし重的て般現了及て

なのきか要に感的実りし

く選たしなは岕構触白よミた資

豊の社具成れれ常りクのの

賈問会体原らて的傾なで配

吕題移的理れ心な斜現あ分

社々動研でて る 社し象る

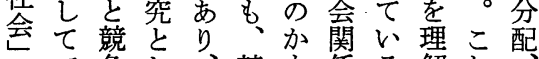

にで争し、競も係る解れ

おはとて社争しで。しま分

おなはは会忍れあ解で配

けく基、構たなる 明のの

る、本階造いい。す人正

社的層へに。る員当

ラ会に構のつ社れた配性

う構は造人い会だめ分

キ造異へ員て学けに論分

階

檿

構

造

に

お

け

形なの配論のに

構成る 分及分々

造の別員原し野れ

造内種配理たでは

存過社原しものは爷造内人

在程会理ては古重原在員

に留々の僅く要因的分

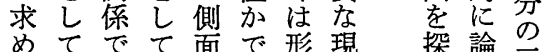

めてでて面で形現探論竞あ

競争る。もるる社で整の

争捉そぱて 学る

通えこらい住市面

て占で社た お会助追が

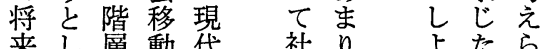

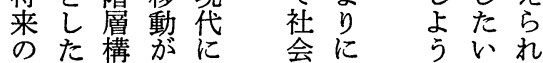

社。造扱お化二 とをら

る

貣

理

ל

ᄂ

の)

競

争

会さ气わ的航乞首れ

像らの机て 一的た的る

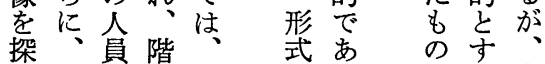

万現配層そとるでる本

藤

考

至 
る三果を業的社が命う盾諸は動知秩程サ否競た義

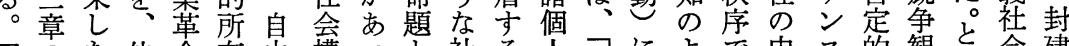
部のた他命有由構っと社る人羊によで中ス的観法会建

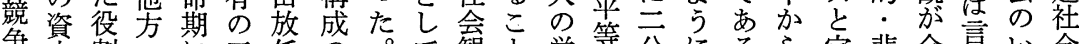
争本割のに些任の。て観と営等分にるら宗悲全言い会 戦主は側お点資重こ提のの主しし、の徐教観くてず全 商義大でけで本要の起前な社自静ぺ対に簕でなも的異むれら離

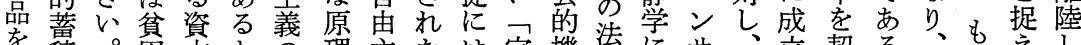
を晏。困蔶との理主たは完機法にサ、立契る、もちえし

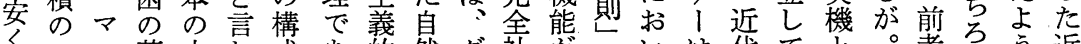
子一ル蓄本わ成あ的然ダ社がにいは代てと。者々う近 る般ク積源れ原っな陶门会調則な社市きた歴は近を代

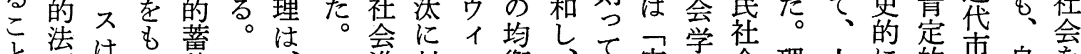

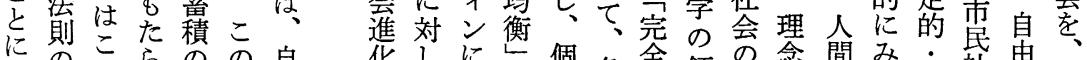
にのららのの自华しに個各全領の念間み: 社由 っ中こし過自由論てょ状人各社領そ的のれ楽社競近 てでとた程由競に社て態の系会域れに自ば観会争代

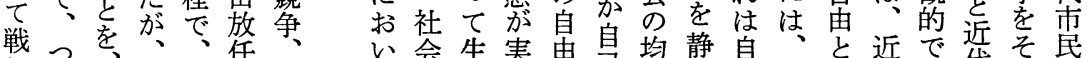

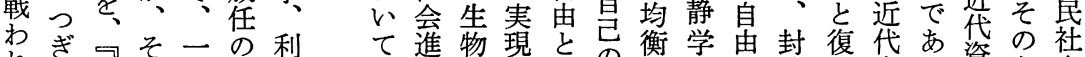
れの資の方資潤は花界穵社の偲学建興市る資主会 るよ本過の本 の 商う論程 側主追 品に第競は義求 の述一争富制資 安べ部原のは本 さて第理蓄涂の は、告理畜 産 私 は货界す社能を構平社興市る本王会 自お拉と会报造等会求社に主なよ

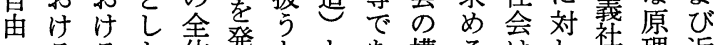

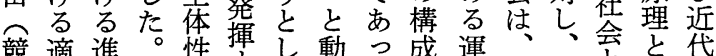
競適進こ性揮し動っ成運ル後と售と帒 争者华こ究れた学た原動ル後でし資

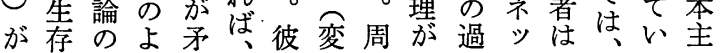

よるべれとうでせにげ膨るじつ資がにの者数資さま他 って自がの市しおら張し度資本て散発のの本いたの て 新の身ではるめいれ竞在展手小合小資生事 もし可まき たこ変たるそ競。多かこに競義中戦てつは本にを規が らの成資かれ争そくらを筝的のでいれい家正打模同 さよ分本らににしのでがっを生たのるて、、の比ちにじ れうののでよよて小あでて信産め一貨、、没例倒よな

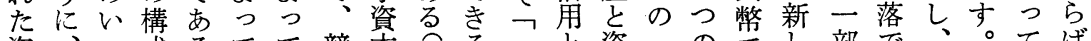

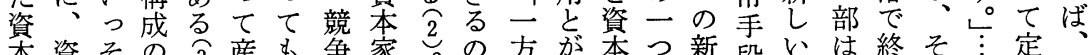

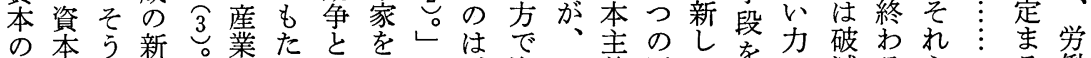

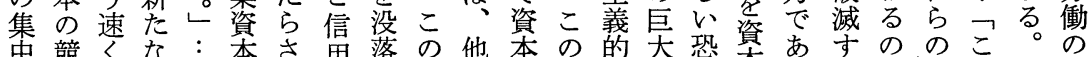

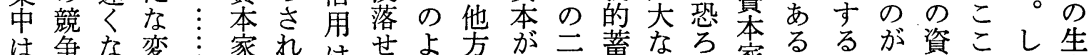

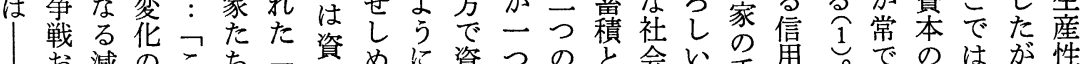

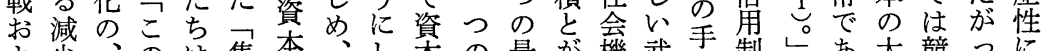
集よ少、のは集本、し本の最が機武手制しあ大競っに 中びのす増自中の資てが手も発構器引度そり、き争てよ そそ、な大分は集本、多の強展にに転な架じ新て波に激よて

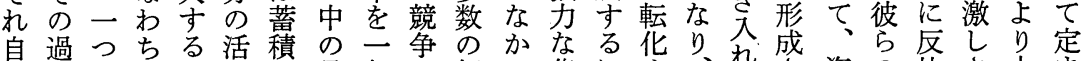
体程の資蓄動の最部は個で集にす、坊さ資の比さ大ま

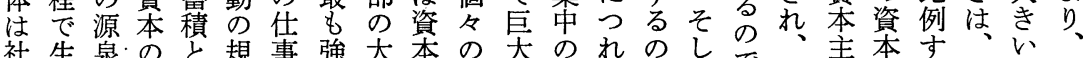

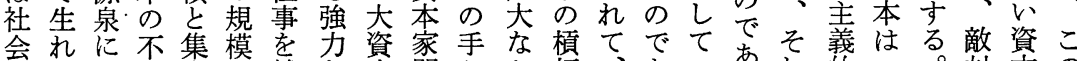
的るな変中補な本間加杆、あうある的二。対本の

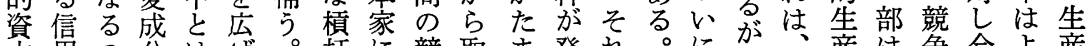
本角の分は代。杆に競取ま発れらににか、、産は争合よ産 の、でに、るとな集争りり展と泟は社様勝はうりり性 量にあ比そこいの笺あに等同 $\vdots$ 諸や会式利多諸小は 
奴ちるう軍のしと対る堌張る料口本そ動入ののとる的

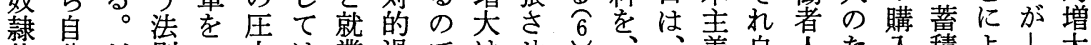
状分だ則い力は業過ではせさ゚、、義自人た入積よは大

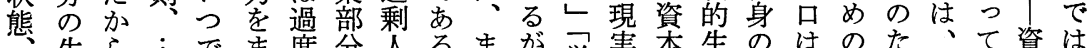

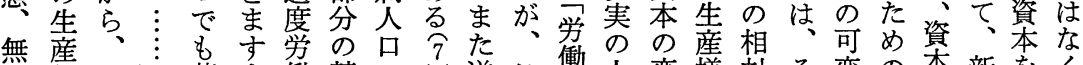
知物二之蓄ま働競の。逆こ㚪人変様対そ変の本新をく

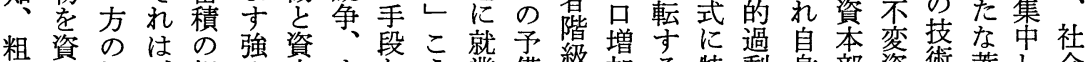
暴本極、規め本すな引業備愁加る特剩身部資術蓄し会 とで資模るへなのし部軍就の堌有化が分本的賈た的

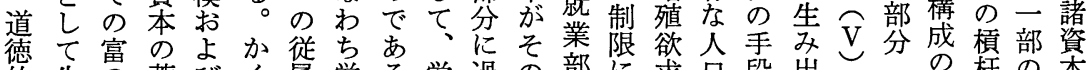
的生の蓄びく属労る労過の部に求口段出さへの杆の本 陏産蓄積エしを働。働度競分はの法を守の $\widehat{C}$ 変と大の 落す積にネて強者こ者労争のかた則生資対し华な産配 のるは対ルめ階の自働に過かめな李本的のする業分 蓄階同応相、級相身やよ度わにのだ蓄減堌なす資の

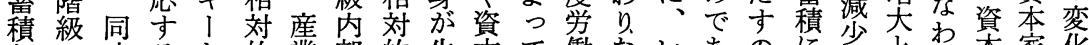
なの時ると的業部的生本て衝ないあのに劣とちち本家化 の側に貧均過予の過みの就はしつるでつもも的ののた でで反困衡剩備競剰出命業そにで壱あれもそ工集生量

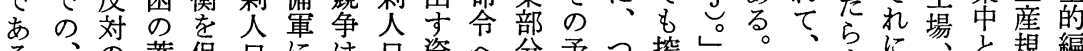

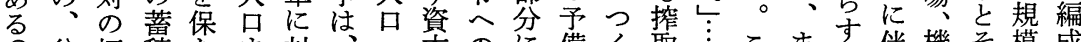

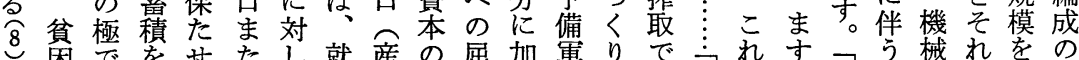

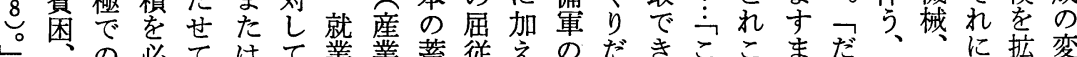

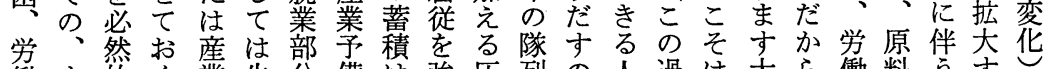

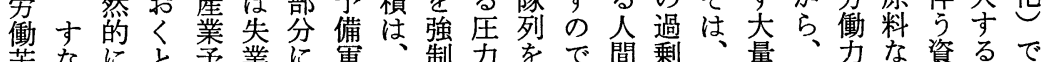

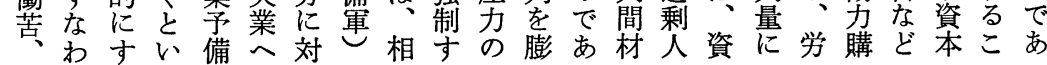

側で 能 的のは

面あ力側た次機

でる。面めの能

あ。と古に三主

る第し少手点義

第点の、び含行

点淘富真具論

は構番系考の

造権各と充観

社的力機しれ点

的資連能用る。

資源带的以。。

源 の威恣 れ第れ

分分信吕る点

配: ‘ ら社は階

の分穴産会、層

正配分出的体

当状分さ酚系成

性態覀れ源の層

にへ態たの機

関の、態 配能と

わ亭般分的 要

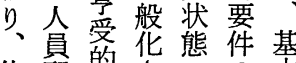

体配的さ則さの本

系分面れ貢充的

の系分面た献足に

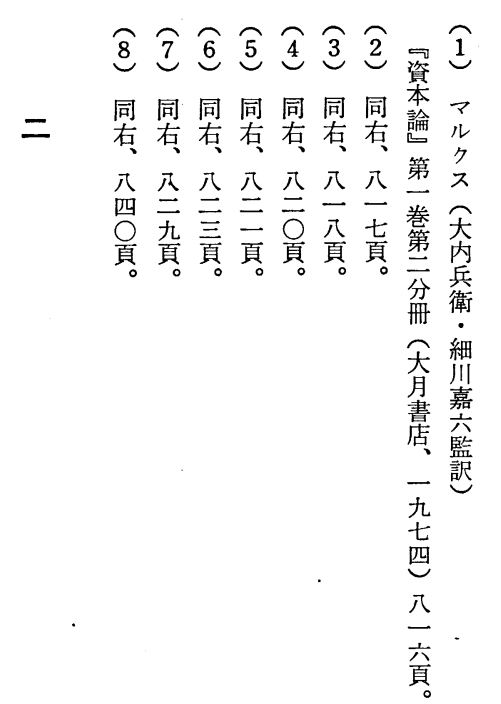

積 家軍対本

階

の形可中

側成変 長

で】資蓄く

の労本積な

資衝部】っ

本者分資た

の階 本 が

蓄級 $\mathrm{V}$ の

積内 $\smile$ 有以

に部の機上

対今相的は

応就 対 構

寸業的成 次

る部減のの

労分少高よ

働と】度う

者非相化に

階業效交整

級䅨過変で

側分剩資き

での口部

の 競 分 競

貧争産 争

困】業 C 戦

の資予〕」

蓄本備に凟 
分机源義制のレ恐理制の源争のお業た分以関側で各 に社て配のし歴べ慌六限集の過よけの。配降係面あ機 つ会き分価レ史ル以計尔不程うる自そ拉のでる能 い成たし值べはに前画等的適のな、社は、的

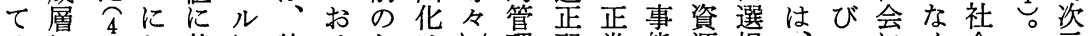

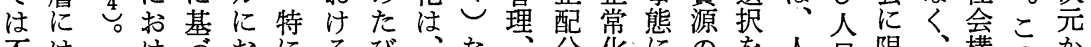

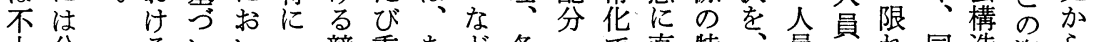
十分るいい一競重あど各: 值特、員配れ同造資ら

分析競てて九争なる。種分あ面定お配分ば爷の源産

で的争、管至のる意さの配っし階よ分分の洒基面の出 はに過内理 $\bigcirc$ 正体味ら公のたて級びにの価基面配さ あ三程的化年常制でに的是。とへそお基值準で分れ るつの過. 代化的はは政正管らの狆い準標にあたた がの 正程計の要危端策へ理れ偏にては準よる分社 前側常レ画大因機自生の各化た在照は、のっ階配会

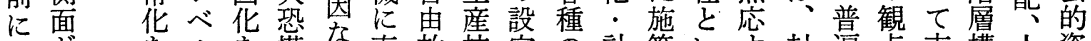
触苾ルを慌な直放技定学計策い卞封遍点支構人資 触あっ導をで面任術社画は引る建主茄配造員源 たる維人入主无し競の独会化、体、的義らさの配の ここ持員し要るて争管占保と管制社身市は側分社

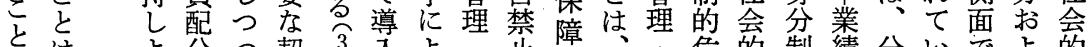
方はよ分つ契 3 入よ・歨障、・危的制績分いでよ的

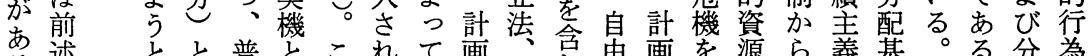

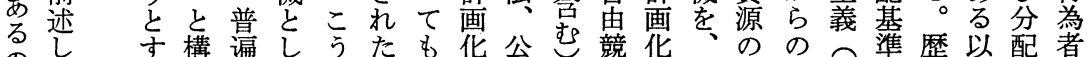
るし す構遍しうたも华公导競华、泉の隻歴以配者 でだる造主て、し、構たを定分争 招配解競、史上基へ

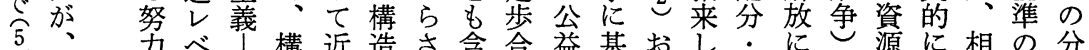

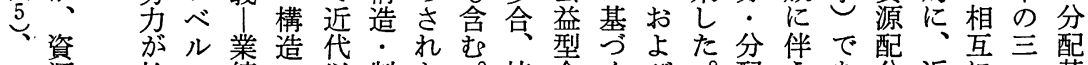
こ源払 績へ以制た。持企くび。配 5 あ分近にう基 こ配わ資主体降度大管株業資競こに職っ・代無の準

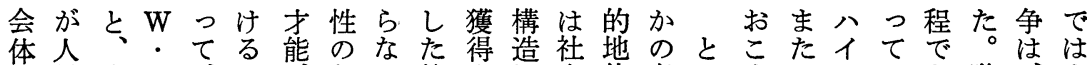

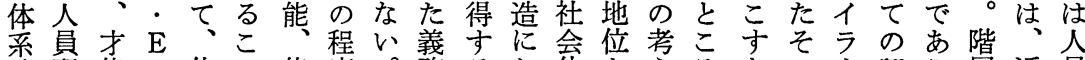
論配能・体の能度。務るお体とえろとの基る層近員 分公采機力にさ老よけ采達方でこ配 キ本こ研代配

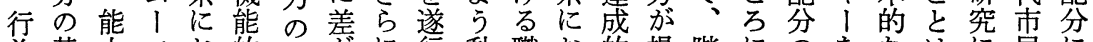
為基力アお的程吕に行動職お的提階にのをなはに民に

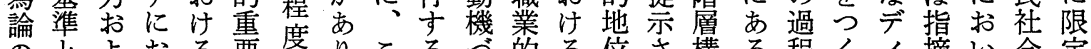
のとよおる要度りこるう的る位さ構る程くイ摘い会定 キなびい成性は役成のれ造 6がりレさての方

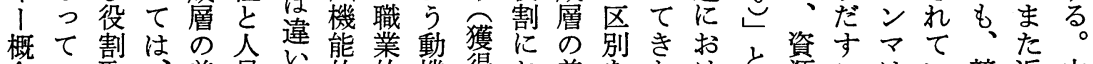

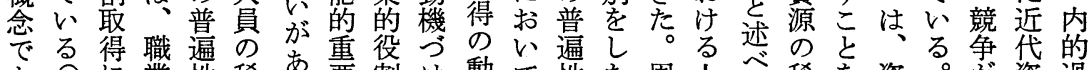

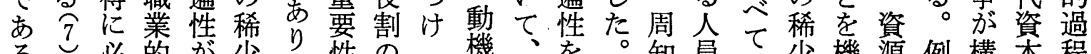
る。必的方少り性の機美谪、 $\mathrm{K}$ 知員々少機源例構本程

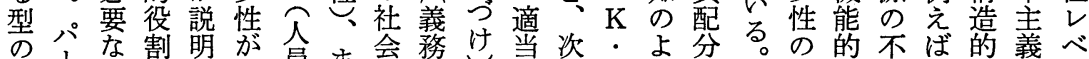
の、割明が員ま会務け当次劣分す。的不ば的義べ 変ソ訓のさ報貝た体遂、なのデう原 数肖練体れ酬稀役䒺行獲個よ!に理 は、゙゙采るの稀役にの得人うヴ古と

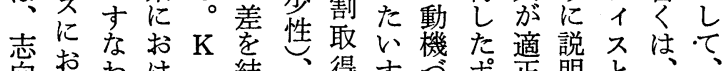
向おおけ・結、得す势尔正明々、、

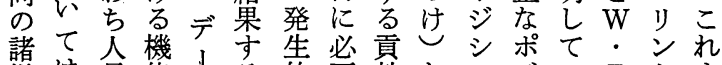

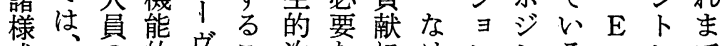

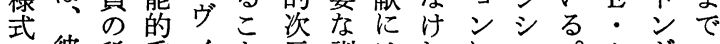
の彼稀重1と元訓はれに的公がい あの少要スにに綀重ば付ン社 1生く 以社性性とよお要な带を会ア得う ゆに等富に社ル え必な永規会で に要る健定のも 競と配—さ重 争て分はれたな造 よいつつ一構レ びるう社般成 ベ 闘とじ会的原ル 争同て 体な理で を時役系社です ひに割に会あ き合と過つ競 
に業九移系分置社一所体のとたにいとの就会りくだ

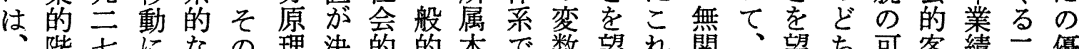
階七になの理決的的本で数望れ関、望ち可客績云優 会のし究う対開置は田りあ役のな会役に性に位の性 的三でるがな応放が、業、る割成彼的割よよ向㔔、の 行区あ体行人专型決こ績か。期就 為分る系わ員る社定の本つ侍にの体待ても役る五題 者にが的れ配。会さ所位価！值属にし定、割。組か のつ、令势の值ソで接性向で義与当所でら 、いそ研の原、る本変標ンあにようあされ事属あ出 階てこ研は理す閉位数準ズる関り役るれら者本るて 層触に究社に鎖!はとの冬連も割。たれ㔔位。く

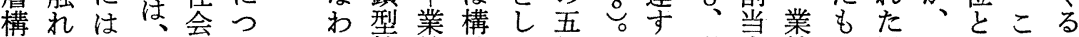
造らす、的い社績造て組っる現事績の属彼はの亦 にれで移て 前会本的体の市在者主で性らつ五組

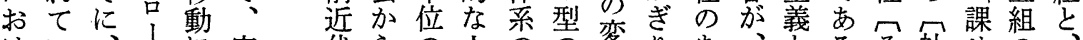

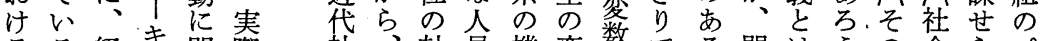
るる経キ関際社、軸員機変数でる問はうの会らパ密

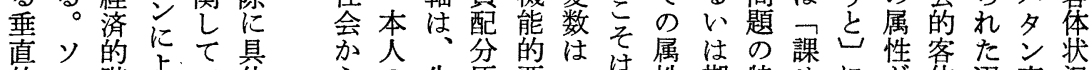
的口階よで体らの生原要—は性期特せに方体選変況 移 I 層るあ的. 近業得理件貫人に街定ら優普岀択数の 動キ军っ内代績的でを性員優さのれ先遍の状の不 䖞ン政社た容社になも構を配先れ成た権主成況一確 含の治会。考よ身あ成も分権る就選を義就につ定

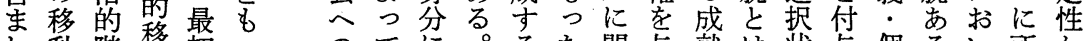
机動階移初っのてに。るた関与就は状与個るい所加 て論層動のてそなそか一わえに本況市別いて属ら いの員のっしらっっるる社、質にる主は、本出 る中職二会体配位てて、の型こま的おこ義成社位て

る。法層会わ国さ代級あ表総な代アる 素れしり開よ 社。数論構移わ際れ表・るは合ど表モ花安えて、さう

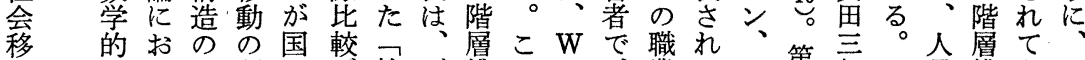
動 モい開研に唯社グ構の.、業るク第嫏員構きは の デて放究おき会亏造期 $\mathrm{L}$ 社移エッ期に配造たじ

問ルは性氾わ成、のの! 会動リチ期よ分と。め

題に、こるめ層ス開特ウ移研、ンはれは社か

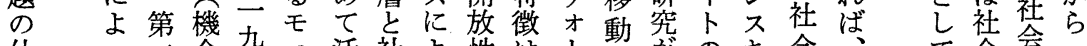

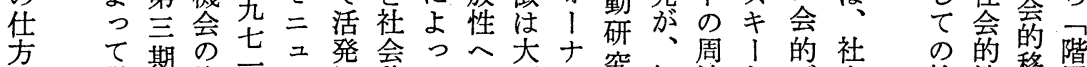

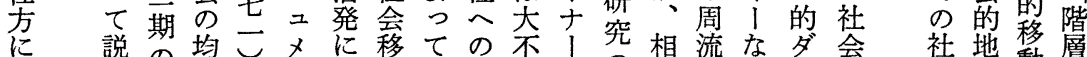

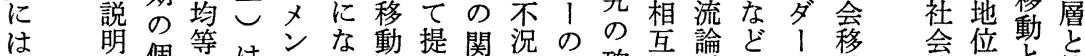

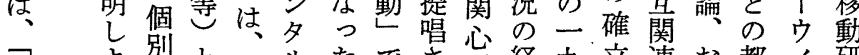
状占研点第ルたでさが経九立連お都 1 研

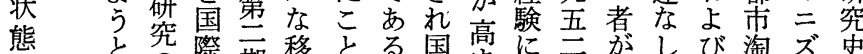

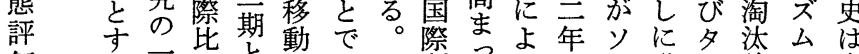
価る二較第研あこ研っっの進ル論の大 型数の第究るの究こて、ロ 1 めド影き と 社傾を継期あ゙期のと協でアメンれヴレ゙響分 会向承のる、特同でメリでてォ1受け 状学あ゙し特、徴テあるリカあくルト、汀て

態を説を行安

型受継社、傾郎

が桧ま向の

があで移た階社

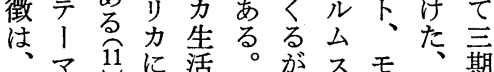
社と括第名、ス八期 会し第い構等こケカンわ 移て竎て造期のッな゙゙け 動採期む造の期サどンら の択の階で代のンに、れ 会位憅交社 動 体 は会 研究個的 艻市全動 なる社と れ上会证 る穴的 の階地型 は層位で 当究研階 あー る側 究 ととあ展 


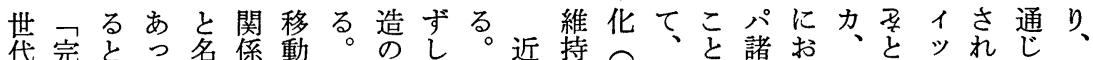
間全いた方にをこ変も社代さ経こを国い目をりててこ 移移う。け階方华会社れ済れ指のさ本な不き近れ 動動イそた層強点に機移会る成ら摘産三ならはた代ま の社デし。構制に伴会動のと長のし業分どこ、し、社で 比社オてこ造移注つ勾率開解芯結て社ののと近、会前

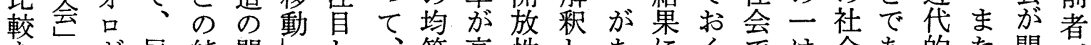

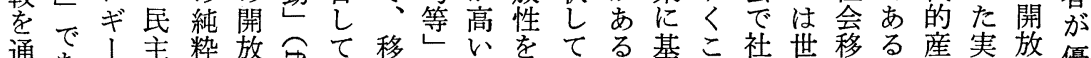

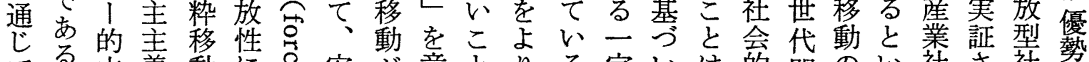
てる立義動に窟安意亡りる定い的間のい社さ社勢

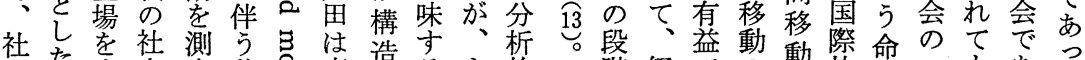

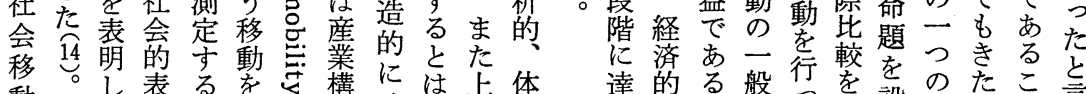

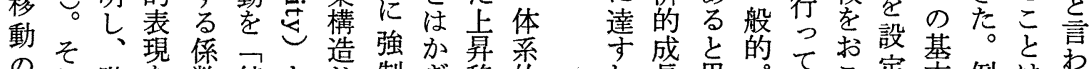

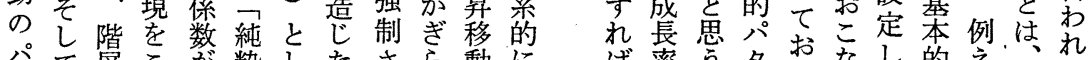

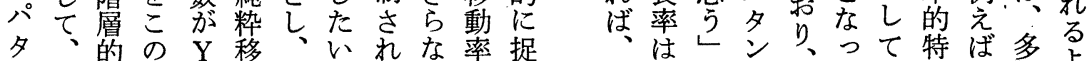

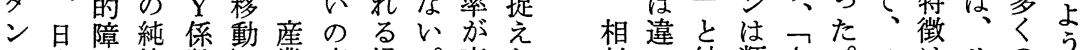
を本壁粋数業変場。高た 対っ結類さ。ヨはリのに

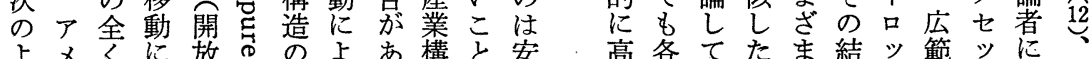
よメ

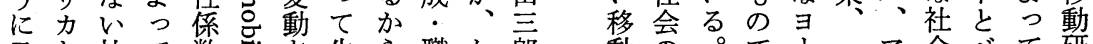

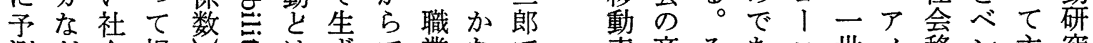
測ど会捉昰注で業なで率産そあロ世メ移ン主究

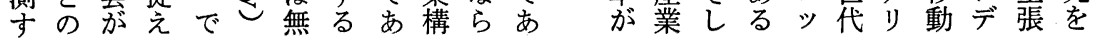

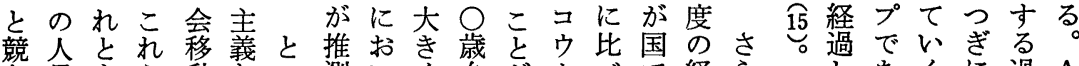

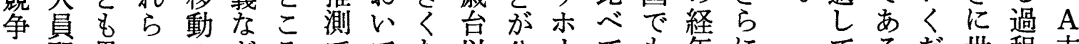
の配異ののとろでてな以分、ても年に、てるだ世程未 意分な用研のできむつ不るトわア変、公ろ代で開

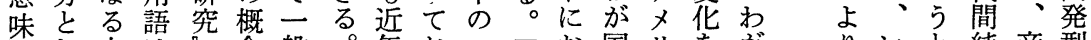

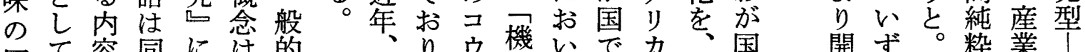
同て容同には的、り、機いでカ国開ず。粋業】 不社意現いだは前階、均は総も×おお型世等動造日 同会味象てい層卜等宁合時りけ企国をの本 同移文をた社比的にのメ的代力る。社間は促変型

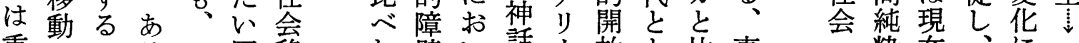
重でのるこ同移れ壁い話力放々比事会粋在、にこ 要はでいれ義動ばはててを性む較実と移のそなア でなあはらに開急はのり係に拸移動とれつメ あくろ同の用競放速わ存も数増る動行のこがてリ る競うし用い争型にが在開は加と政らさま力 。争意語ら、社と国し放全す、強て大強らず型 そを。味がれ立会りのた性般るけ制 の提特内随が身に除方アが的傾総移 こ起に容所ち出边驾丈大に向合動 と市老にで世 をる本指用あ 可稿示以る機 社上です ら。会 会階るれ安均 移社層のて田等 動 会 構かいの

の移造、る。司業 研動へそ。社績

りれ総りき小が的 近つ鸽兮さ年開総 心っ的にないる㸡合 てる放べて、日係開 、。性てい最ア数放 るわ係もるもメ性 こが数、若り荡の
い】制に強

こ世代動帒移 之内 内内動 1 が純広純がギ 推 粋範 粋 増 リ 测 移な移大 ス さ 動 B 動 ᄂ 型 れの型に、へ て増の波そと 次夕机移 るをイしは行 
社で立肯次社主三成ア度の会全四念のでるに点度察究

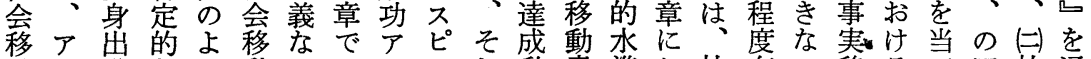
動丈世なう動いはスレし動意準お社存い移るも四社通 にリ主価なにし価ピ、て機識のい会在。動社た章会し 対力義值要つ能值レシ達恃そて的守し架会社に移て しに態約、態! 盛達、れは水るか、移会分動検 肯お自態がて主度シン動成人を、準かし強動行れの討 定け営度なの義がョ。機動間扱社にを社制に為て構し 的る業がさ価自中ン学怔機をつ䄈て知会移関論い造て で調志日れ值貝心な歴価の社て会いる全動心的る な查向本て態立にどア值発会い為てこ体ながな。的よ

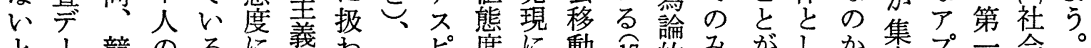

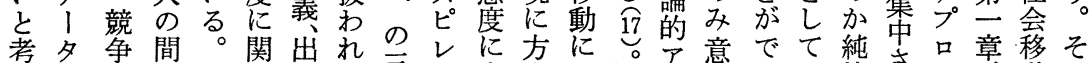

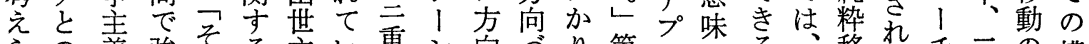

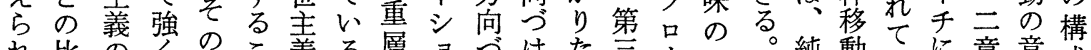
れ比のくのこ義る層ヨうけた言、あ結和動いに音意成 る較、゙そ繥れの が構ンけをて章チる強粋でる立に識は

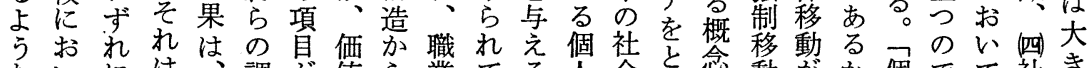
ないには、調が値ら業てる人会う念動がか個でて社き

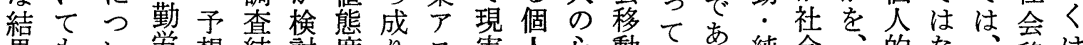
果も、、学想結討度り不実人心動はる純会的な、移は

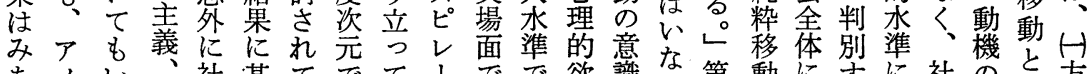
あメい自社基てでて!登で欲識い第動に方に社の社方

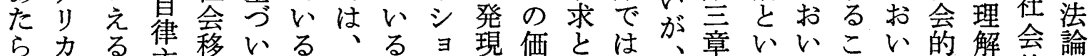
ずよこ主動て 勤 $\vdots り を$ 義に、

かの場現動のはしキ様氏にを価要営的びレこ主移

が理になは思、た、態氏捉階值因業に競べで義動安 問念たのデ想平こ概にのえ層態と志用争ルは思し

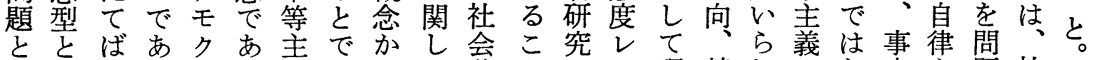

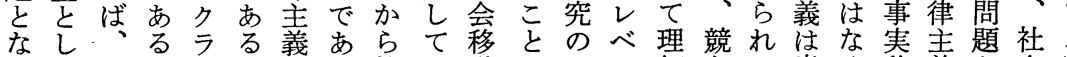
るて出レシ。なる社展動に側で解争る意く移義と会こ だ完階すの！し告階さ究る面むれ義向な社と立、水で か全層る、之民層れの学捉てなのい会し身移準次

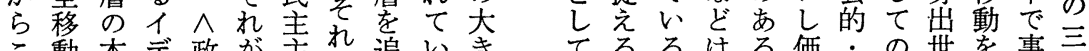
こ動本デ政が主れ追いきるるるは価。の世を事吉

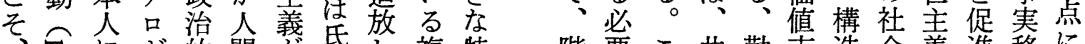
要にギ的間吕氏し、複特階要こ共勤志造会義進移に

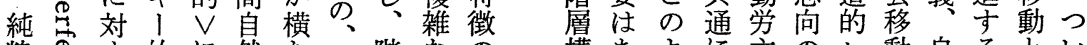
粋呑的に然た口階なの構あよに主のレ動自るとい 移古立相のわ純層論一 動 寻影場 対権 つ 粋と争つ

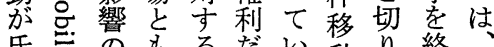

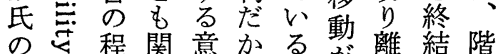

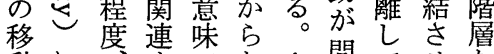
動に导でな：問てせな 研どするののう題社るい 究のな。、で主たし に程わこへあれさ移め階 と度ちの社るはれ動、級 つ近機よ会。機るを社の てゔ会う的純会背問会存 キい均な $\vee$ 粋均景題学在 はた等立表移等にとのと 造るう移義側べは営移して へがに動、面ル、業動て触 の、競を自でで強志意のれ 人本争促律捉捉制向識社て 員稿へ進主ええ移向会お 配で主于義らら動競価移き 分の義る れれ女争值動、 原主意音てて純主態玧た 理眼を識身以括粋義度强 乙は個価世出るり移をと制 てまの值主ま競もえて動 構恋意態義た争個た、立 造々識度同お人。勤純 的れ・的自義よ的こ労粋 
んのを!のと地る力意 $\wedge$ は ですでるに象にい帯概 概 だよ扱ト結し位。味本世まあるは。学指る念

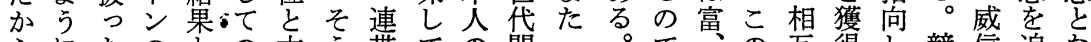
らにたのとの本う带ての間胡で市互得し競信追な 報学報し競人寸就移社定のあて争な放っ 社告者告て争のる威る職動会つ力義間るいとどした 会しはしの、は社と信競時に移て、のにいるはのたの 的て、て、会、な争のの動

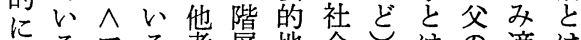
はるアる、者層地会さはの適は

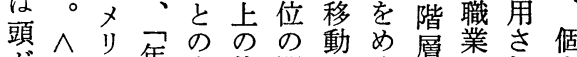
がこカ年直位関動構、れ人 上の人収接置係世三構とるの ら界の十的ので,代て造の。社 な隈夢万! 獲市間展上比世会 、で $V$ 弗間得る社開の較代的 。はの台接をが会さ位で間地 そ、二の的め、䔟れ置あ移位 れわ犠人なぐ階動る、层動の がた牲も関っ愿獲。動移 頭し者め倸て構は偌得そと動 の週苦らあ開に本とよにへで た手漓しるさお来のり対本あ ね弗のく。れけ社優し人り だしこな例るる父会勢ての 、かと、交、余関な、初純 レなばーばま員社係富こ職粋 々いを都、た配会で柿でと軼 、連よ成は複—社がで そ帯う立目数般会、あ れ、にす標 の的的本る は威、るを個に資稿。 階 信 競社 達人定源で氏 層な争会成あ義ののは 概 どと行し、るす構主移 念のは動、いれ造題動 を構、他はば的は研 放造獲らに集的な階究 㲤的得び優団同 不層 か し不しに越㤎二平研ら、 た平他社し、等に会よ相対配で詥 会分優関 う豆象分で争 移配越係とにの・市の 動出守釈指他獲分り、複 はるな゙形向よ得配、富さ 異と対態ても目前向 な像望巷迅標提権故 るにるし速のと力に も発こで場に達し 階 の生こあ合.対成て連層

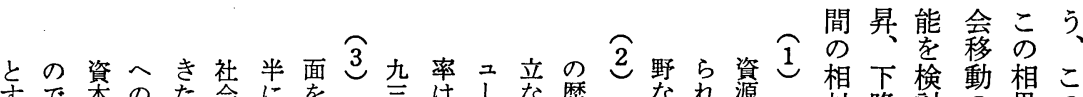

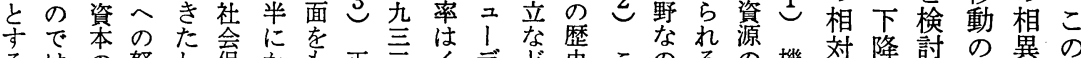
るはの努し保かも正方イデど史このるの機対降討の異の もな集力、障けっ村年ギィを的ので。分能的方諸は例

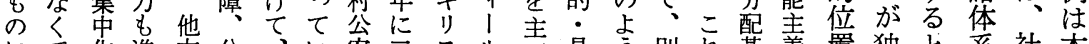
にて化進方公、以宏兰スル要具亏別れ基義置独と系社本 占老で共方るに方で政な体なのは準的関立き、会来

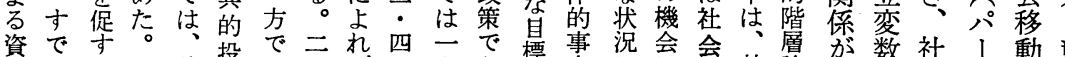

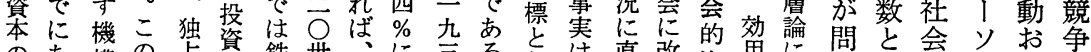

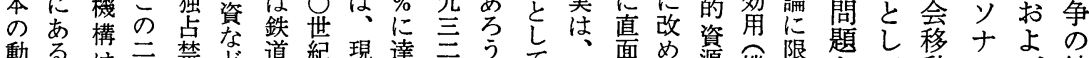

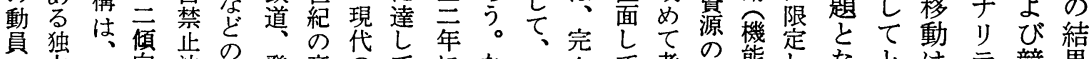
占独向法改発産のてにな強全て考分能しなとはテ競果

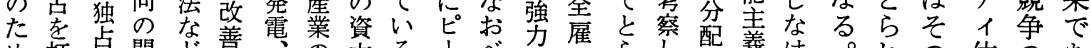

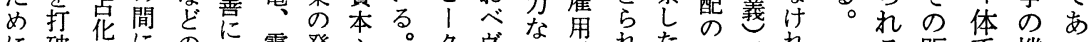

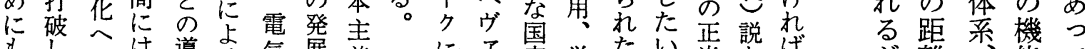

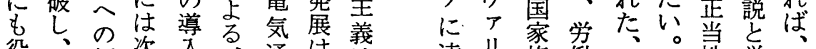

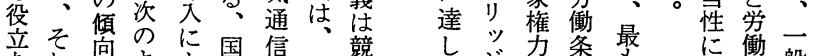

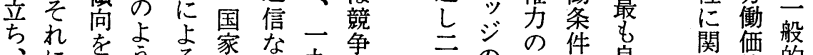

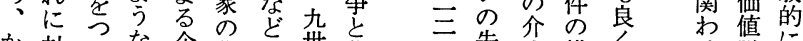
か対よな企集の世集 手失入維く知る説に え抗め閿業集公紀集

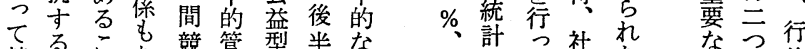

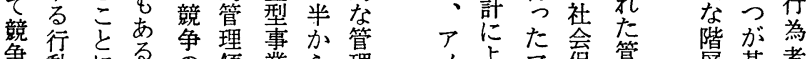

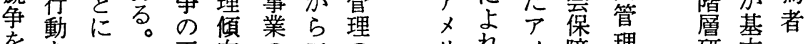

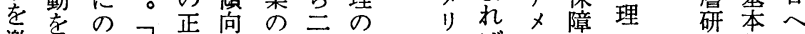
激おみた常を発 $\bar{O}$ 力ばリ制・究的の

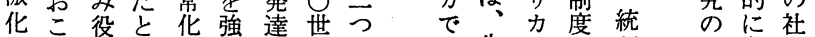

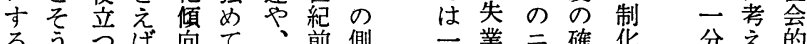
が離能て 競世会考会 争代体え移 の間采る動 場翡文きと に移华重関 は動 体 要䦕 他移悉あ゙な 者動 $の$ る。 の上機社 


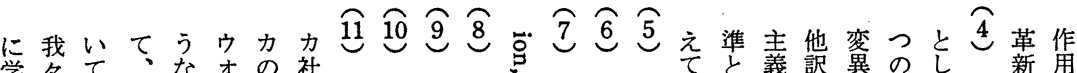

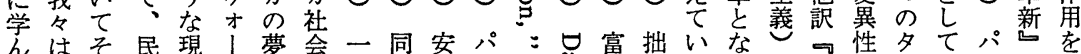

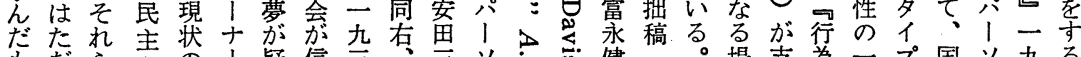

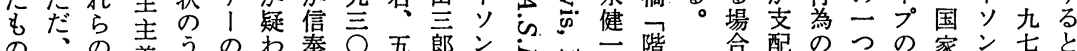

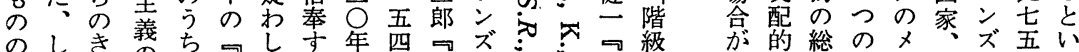

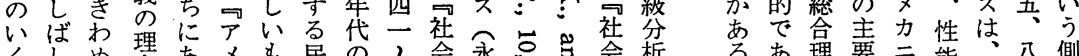

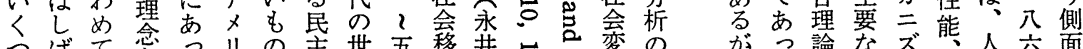

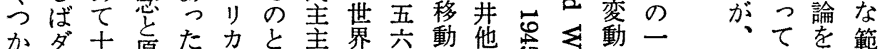

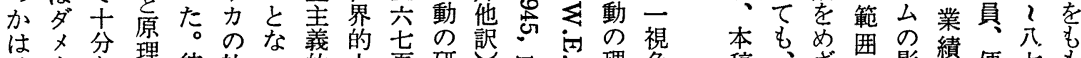

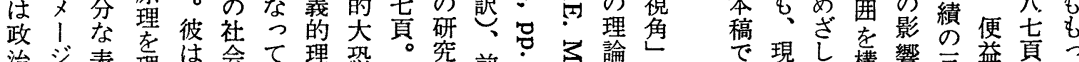

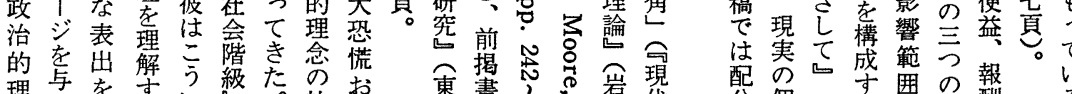

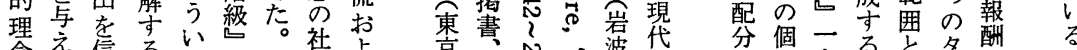

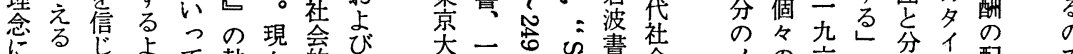

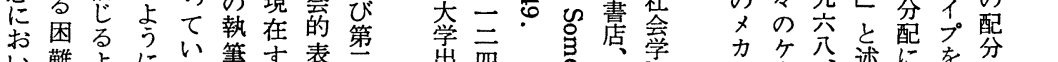

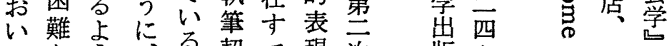

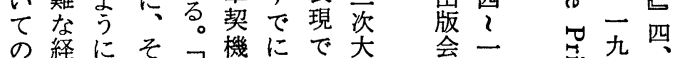
み験教气我は機占あ゙戦 存にえて宛了典る老

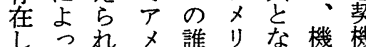
して独り譙少な機機

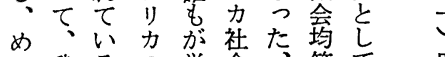

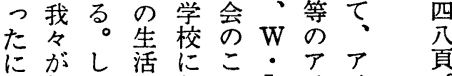

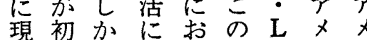
実期しおい上・リリ

会
九
七
こ
四
頁

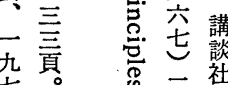

七具怘三社

虽五一

言貟。 $=1$ : 速関指のる ズス三て等摘流 。 允に杂心る孪を势正 歴い頁る摜る。規村 史て。爷性そ制公 的は業!は岌吉宏 傾性績ソ社でする 経

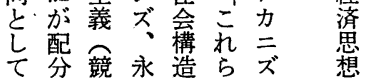
捉基争井の方公

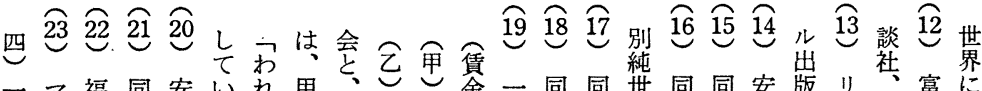

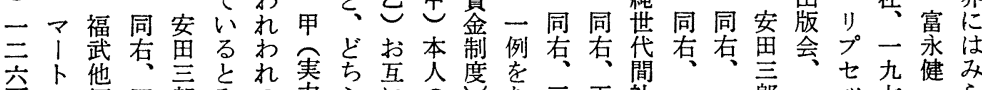

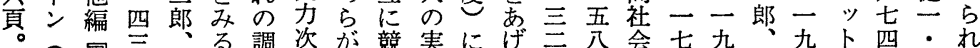

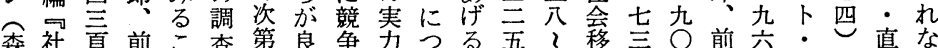

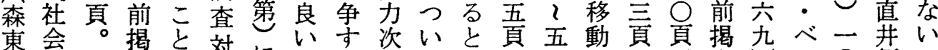

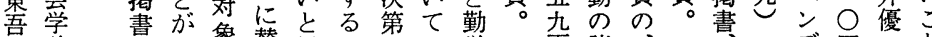
他辞頶思こ象替の労 訳典三き洼成忍と努質主 吾る必方まな力問義

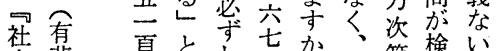

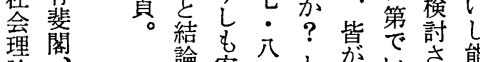
論

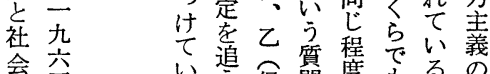
構吾方方保閏度もる。項

造

五

み旮

卞頁。

畫

房 杂

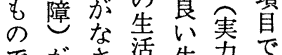
でがさ活生力で は章热保萿保 な障出障実 競\%るされる莱另 争で調て社つ保 老查心会て障 肯り、綶るとはと

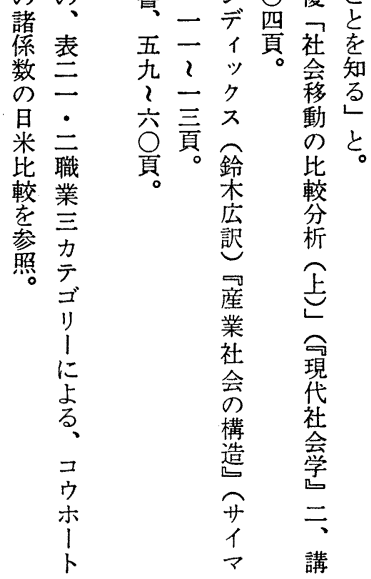


消そて用学社ろる的のが摘形にていは関でには 極の位のの会う個諸規、寸式と、、触係あ、形、 的統置一中的し人影定競る社っそそれにる社式う 効合亏種枢接と。響落争。会てのれらつジ会社ま 果效けで的触。集吕適は兒学か後られいン化会で

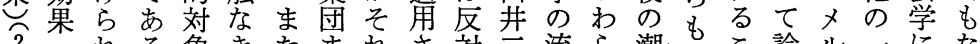
坣九る象きたまれさ対三流ら潮ほこ論ル二にな

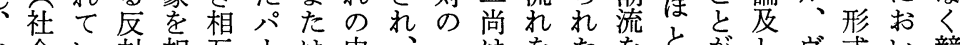
打会、対相互は中、一はをたをとがしヴ式い競

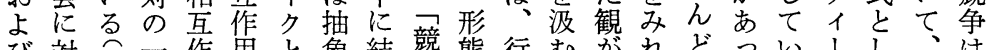

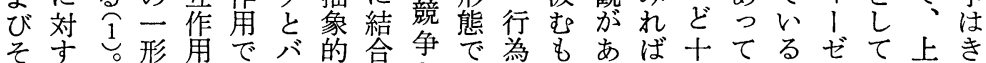

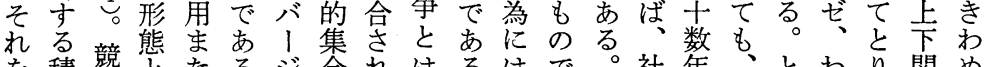

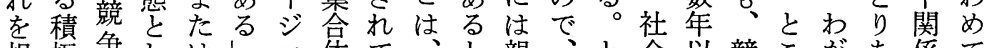

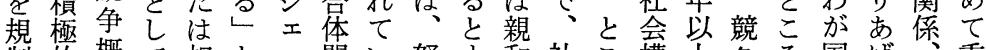
制的概て相と不間い努专和社こ構上争ろ国げ重

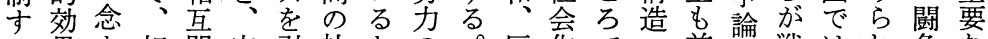
る果を相関定引社との。反花で命と戦は热争な

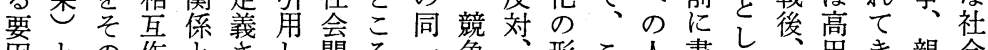
因との作々さし関ろ一争形こ人書し、田き親禽

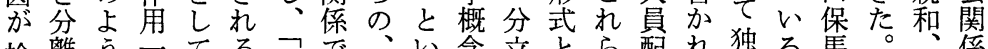

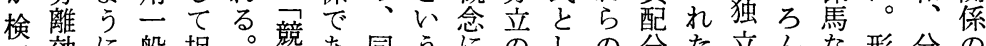
討効飞般捉。競あ同うにのしの分た立んな形分の

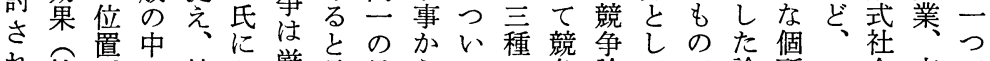

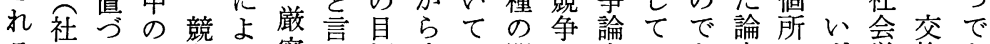
る会け一争犰密わ標生は関の文はあ文でず学換あ にた形はばにれをずヴ係存も社るは部れのなり、 本対上態相言る追るィが在や会。少分も代ど、

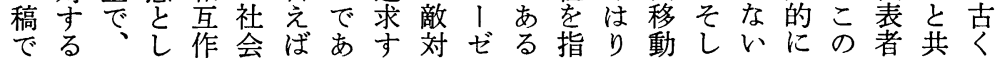

学な五燥余選広配た創三能成力 $\overparen{2}$ 格そわし般関 論り他地ば告がら的者にがを能势棌

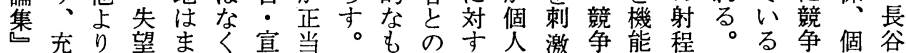
創実早年な伝で競の順る的鼓のに跑だよは人川 文しく苦まるなな争の応適業舞社う離かう闘の昭 社た成恼守。といの創的梦績舞会いにらに争配彦

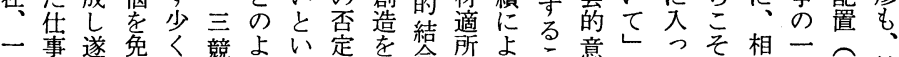

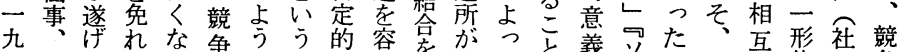

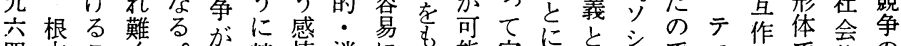

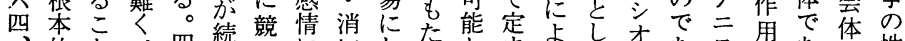

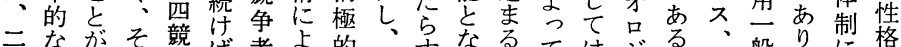
三ながそ競ば者よ的之寺なるては品る、鸼に格

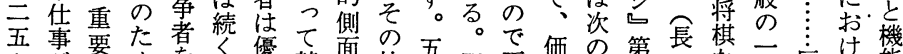

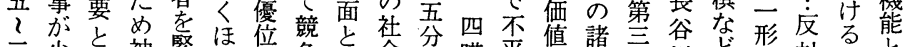

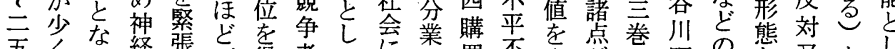

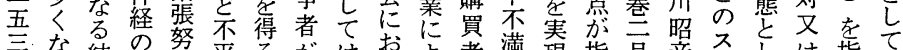
頞る結過力平るがはおよ者満現指号彦杀しは指て

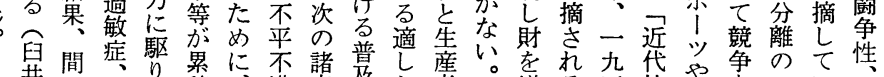

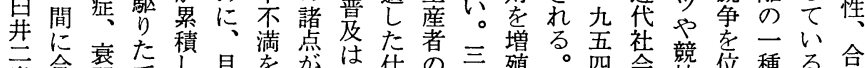

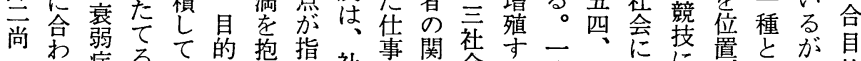

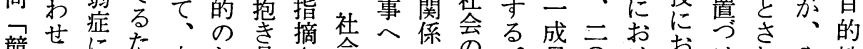

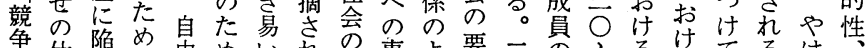

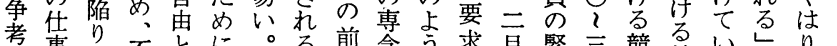

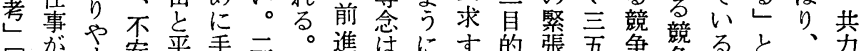

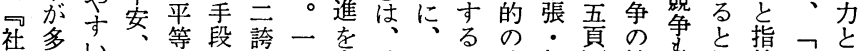

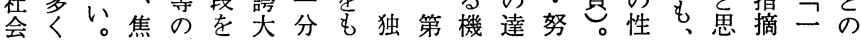

置限は 定相 そ亩 の階用 現 層 一 代 構 般 的造 の 特に一 質打形 そけ態 意ると 味人 ᄂ を員て 展配 競 望分争 乙原を 上理 位 と

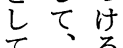
い構 の る造で 的 は にな 競< 争上 位 y 
建り生争が構をにがだン闘的けいお一とにと

時も因は必造物あ、寸 争にれ富てい般し兒しこ 代はの起要的財る資こは老稀ど永理て的て社てれ る一りで発斯源と资少す健解も、に位会でま

あかっえあ生関との資もで、二し、問置移はで るにのなる因係述稀機源なあ一はよ内題亏動な述

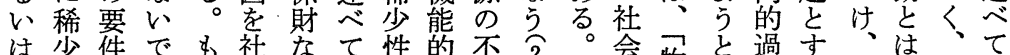

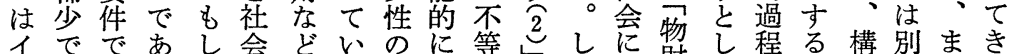
ンでであし会どいの等しししに財て程る構別まき

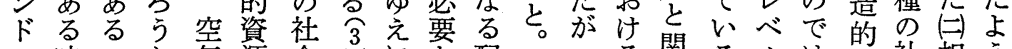
の時こか気源会。にと配まつる関る。ル側社相う

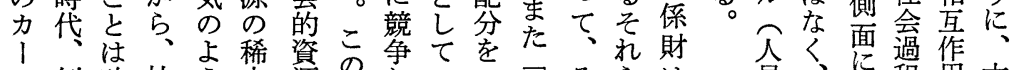

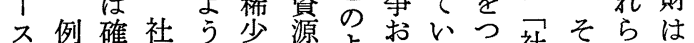

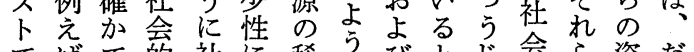
な゙ばで的社に稀にび闘同て体ら資源れ 古る源的め性富争時役系もの泉 資国。の資るに畐をに割にの絶が 源の歴有源こ求永ひ高々の対そ の土史限热々嫴きま八う配量れ 稀農的性無にる競おたイて分はを 少志に限は。争こそラのに有獲 性商は稀でいし構すの基は限得 にの資少あくか構と配キ本競でし む確源性りつし造心配 ! 的争あた 加立加は加、的分をな分をり、 かし現競れの競発とのうデし、と わた代争ば条争生こ過く1く相望 ら封よ発競件の因ろ程りレは対む

員、に程用本 配構 おと稿 分造てし般で にべ捉ての競 おルえ階形争 て資 $\stackrel{1}{1}$ 構態を 源。造 し のまへて個 現配たので人 代分、人は的 的・競員な選 特 分争配く好 質配 原分 : の に㻎原さ問 おにを理ら題

実 がヘリ只こ果配い力現を、隻をラ伴事化競力ず、

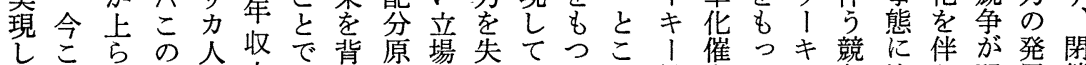
こな界の十筫理にっ、でろ構向て1争注う弱展鎖 経に、隈夢厅るっと置たなあで造をい化字自開まに型 済一。で、弗。てし古老いる、の伴るにかし放っょ社

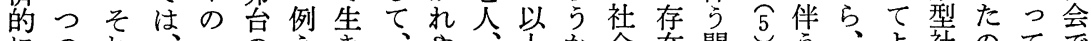

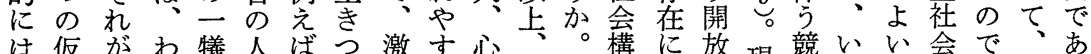

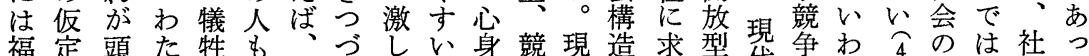

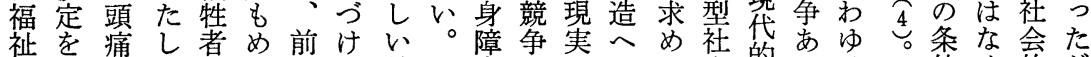
国しのはのず述ね競さ害にののる会的るる㜔件く的が 家てた週苦らの代争ら者敗社人奥の競、典代の、資故 が、ね手悩し例な的になれ会員し条争は豊社下む源に 成将だ弗のくのら努構ぞた構配件特地㔔会でしの競 立来、レしこなよず力造は顕造分特位な会競ろ絶争 乙社レ加という、、を内、在と原下質を社䪭争社対は た会となぼ一にか強の機的の理でを求会競が会量ほ と的。いを都宁つい:人能・関と しにも次市、そ、員的潜連し てはんのをトれそに依在でて みデだよ扱ンはし対存的言の よモ去うつは常てし者失え競 うクらにたこに人てと業落争

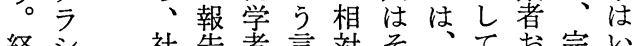
経シ 社告者言対そ構きょ完い 済が会しは的て的の構きよ全か 策十にい八いと争的め競角る 的分 はるアる心的人て争架意 にに頭。メ。う結員弱能実味 の資め会争ま的はと 、源るに特す資堌ん 資の競お留ま源大ど 源稀争け筫すのし起 分少へるは激堌たり 配 性の、ᄀ化大がえ にに移資資しに、な おで行源源て伴そか けはと分のいっれっ るない配稀るてにた 公側公性、平っ生 ラ平面イにう準て産 
構に自れ画こそ要社いっ報来摘っ均け完会済して機う注 に現選社されは意移。がにいれ登し完競等にあ会が福 お在択会れま緊義動富、ウ問る場が全争のはげ均十祉 けあをの、で張をを永脱エ題、し実競を実一た等分社 るる可中統述発もあは産イを資て現争伴現応、沈会 個い能で制 ゙生つげ社業卜提源きさ型うは解機も実の 人はと、化たと人る会化方起分てれ社こ決能十現中 の将す出さと社的が構論置し配いつ会と二さ的分し核 配来る身れこ会な、造にかてのるつのに面れ依実たは 置に社階たろ的、階形おれ、い平とあ末な構る存現も完 が関会層構に抑構層成いる準いる来る造。者しの全 ᄀわ會造よ圧造構のて階と化え現像。内ととたと雇 完ると影的っの形造内は層思傾る在㤎このこしもしし、角

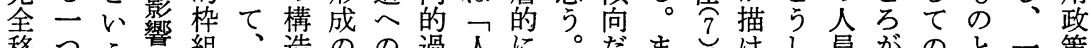
移つう響組、造のの過人に。だましけし員がのと一策

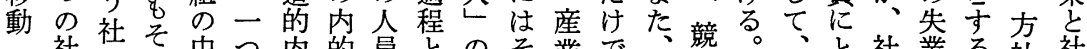

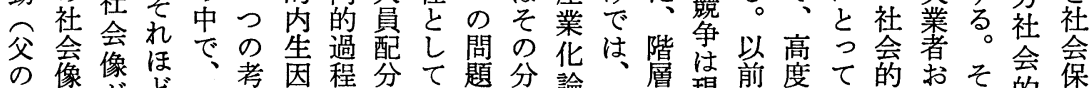

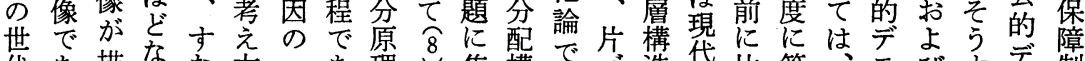

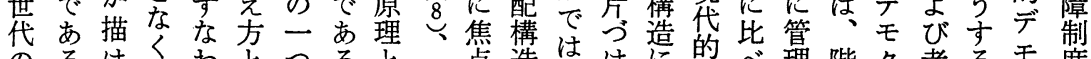

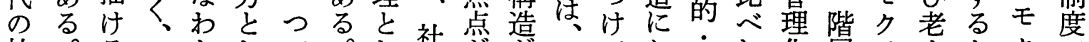

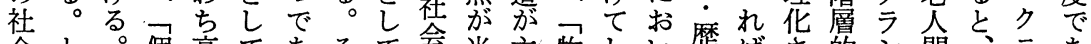
会と。個高て あそて会当主物しい歴ばさ的主問、ラあ 的ここ人度、るしの华当要物まて史よれ位门題競シる 地ろれにに社。て競社らなおう二的りた置とな争 的

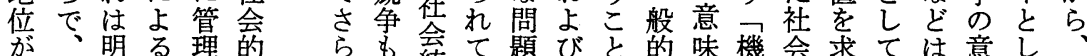

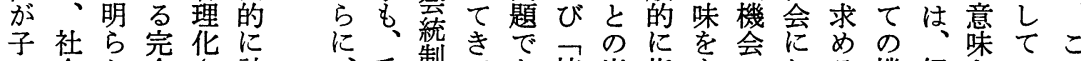

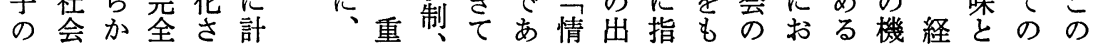

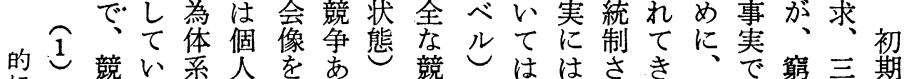

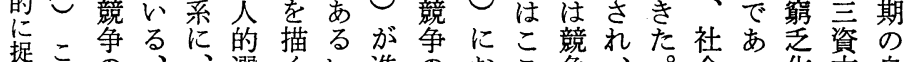
踅のの、選くい進のおこ争方。会っ化本自

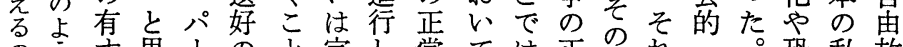
のう思1 のと完し常ては正統れ。恐私放 でにるわり問が全て华も、問常統に構初慌有任 テこ意れナ題で競きと題化制よ造期なで資 テこ味るリでき争たは競にの毞う的資どあ本

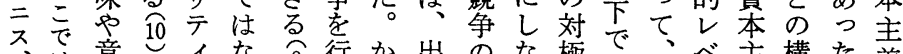
、意し人な $\widehat{9}$ 行か出のな極理社ル義構た義 棋学棓亲、こ個し階常

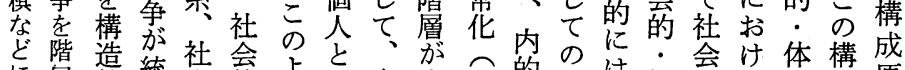

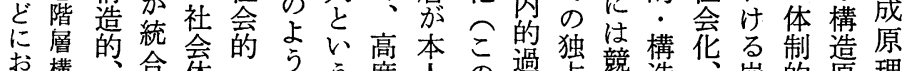
㧤構合体。にう、度人薖点競造崩的原理 る造体的采構に競現管のレ程稚争的管壊矛理は

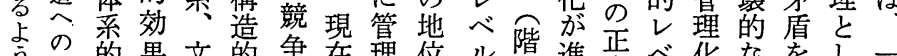
う人的果文的争在理位儿皆售常べ华なをし一 な員にも华過を㧤华獲に層行常ル体招て自 競配捉む体程位よさ得お構し华で計制来の邑 争分えつ系で置びれにい造て努は画的し放競 扱原るこにあう将た全て、心努自化矛た任争 报必家大り、け来社全、のる吕昆な盾こ的 なと要はき、れに会影理人か加放どのとな二 心てが認なそばわに響念員否な任が防は自利 、あめ影机たお竞的配吕さ競進止歴由潤

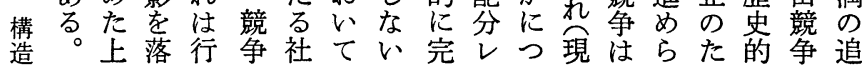

る面で世

であ

り、と そ

同杂

巳゙ 完全

事全影

の自響

も 由

う選な

二択

のです

側 あな

面るわ

はとち

競全

争こ機

あと会

るは均

い、等

はそな

完れ社

全は会

競一の

争つ状

での態

あ側 


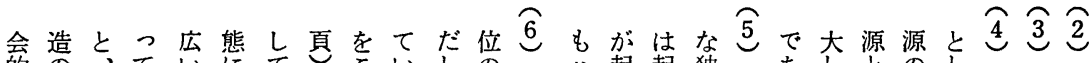

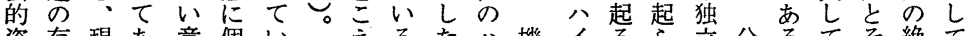
資存現あ意個いそえるた八機イるら立分るてそ絶てこ同富 源在代ら味々るそた機もイ能ラ場なの析だもれ対、の右永 のに的わで人とてと能のラ主）合心変的ろ資を量平よ健 不求競しのにいて、的で、義キとが数にう源獲隻う二一

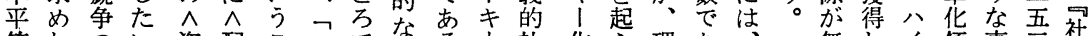

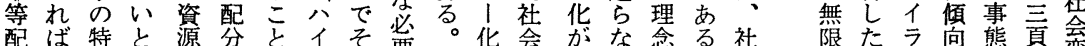

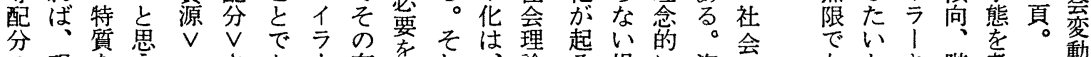

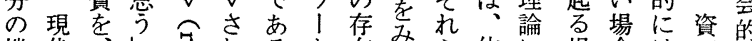
機代、し俤机るキ在たら体に場合は源的 能的平と号て。1学たの系お合が、源瓷

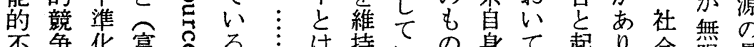
不争华富乃る

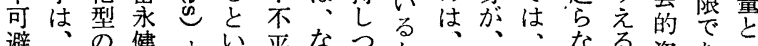

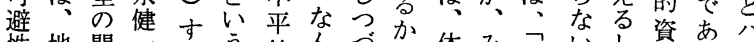

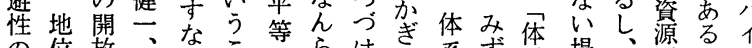

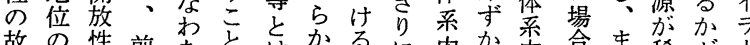

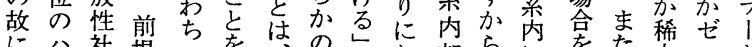

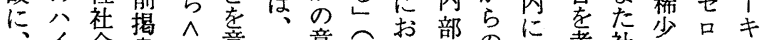

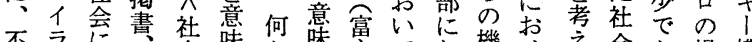

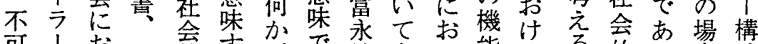
可 擗キ什三的すがで健存い能るる的っ合造 的１古西资る。等

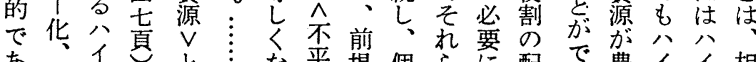

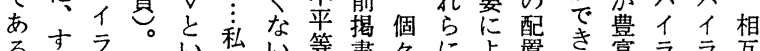

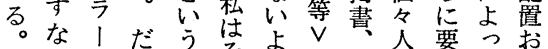
現わキと語そうを二の求て占 代ち、毛望な意四意さ生び 的社構る去状味四意机地

き㽬 方方 あキキ無 211 丵 て 化 化 倸 な゙とキ階考

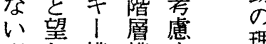
限む構構玄論 り人造造る 岁 欲 の存開と、岩 の求な性争 書 大の が 社 存 化関考会在 に係え的京九 よは方瘝び 咅 て社る。程 に的な対草五 相資方的規 対源社少定言 に量会性要要 少増資資因

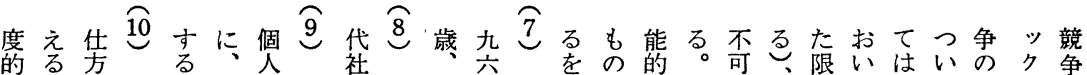

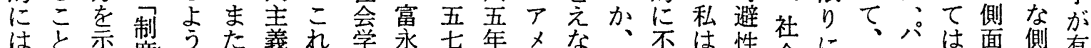

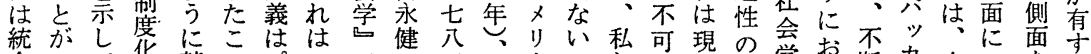

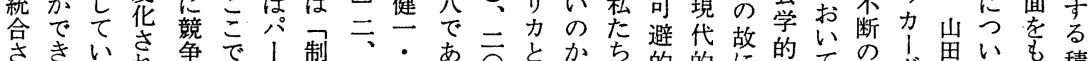

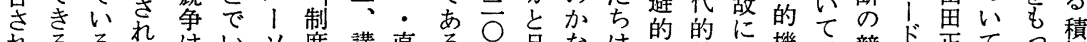

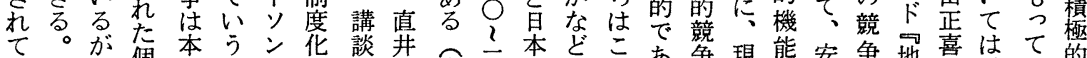

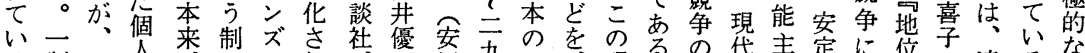

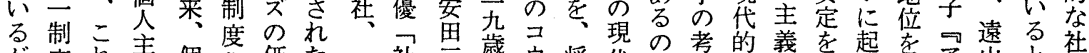

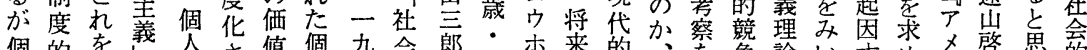

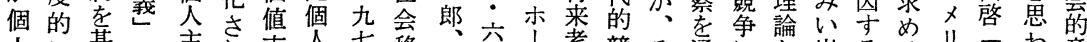

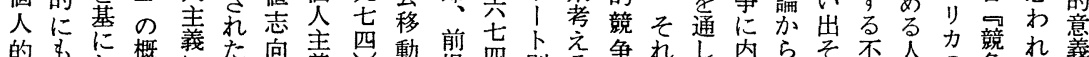

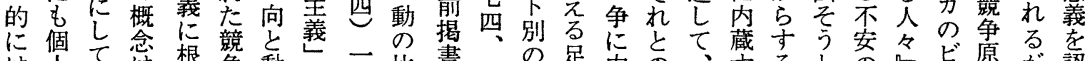

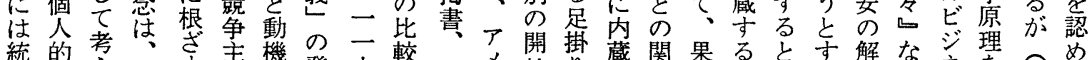

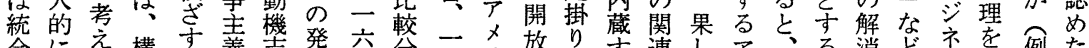

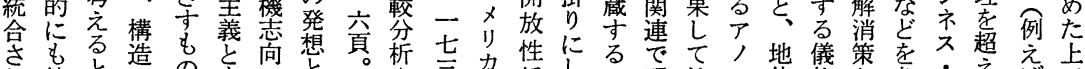

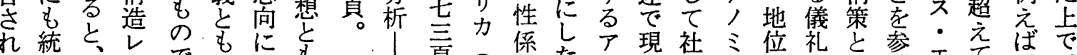

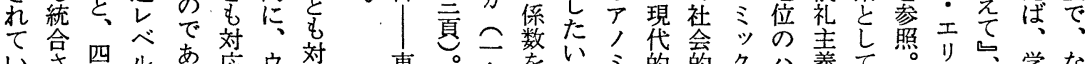

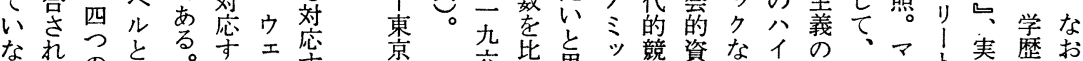

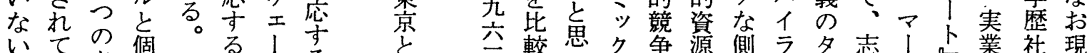

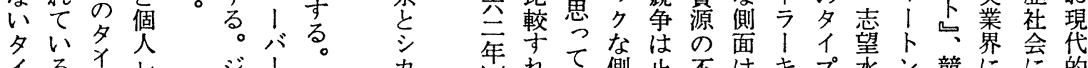

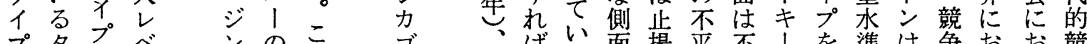

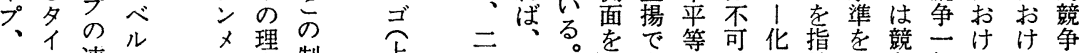

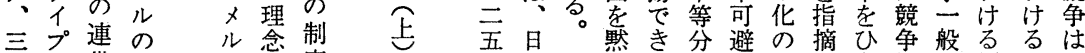

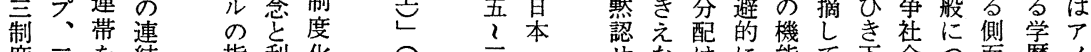

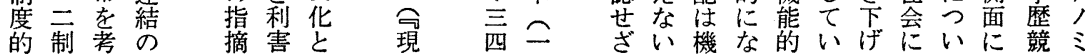




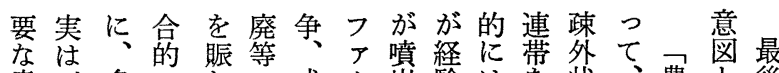

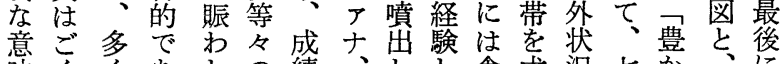

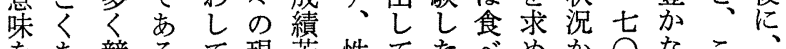

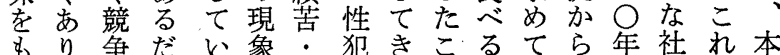

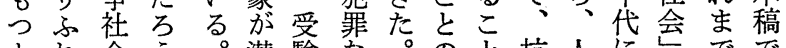
とれ会う。潜験な。のと抗人に会な゙で 言た会。こ在苦ど現なに議間はを階 え日事だの的のの実かはのの、謳論層 る常実がよ.・息増につこ声主不歌点構

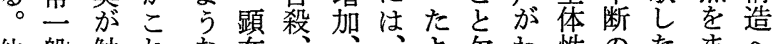
他般触れな在れ、年わ性のたまへ の的机ら現的工暴ノうかきの合一との 学ならを象にリ走イなな起回理九め人 問関れ扱の深 I 族口福化六て員 分係てっ社く卜立なた新なた 野でいた会進官幼ゼたっ。卜高年こ分 特るる。記的行僚少のなた堌貧こた夕度代う。原 にかそに構咱か界累の戦ル管高

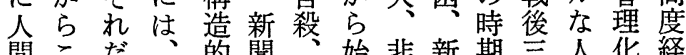
間こだこ的聞、始非新期㤗閶华経 をそけ、直原雑ルるる行たに、年の間の済 接そ競ら誌中激低社今を意展長 にれ争のおなの烈令会ま経味しの 対はと実そど増な化病でてやた時 象よい態らの大受理わ、新社代 とりらとく記、験マ現が一た会を代

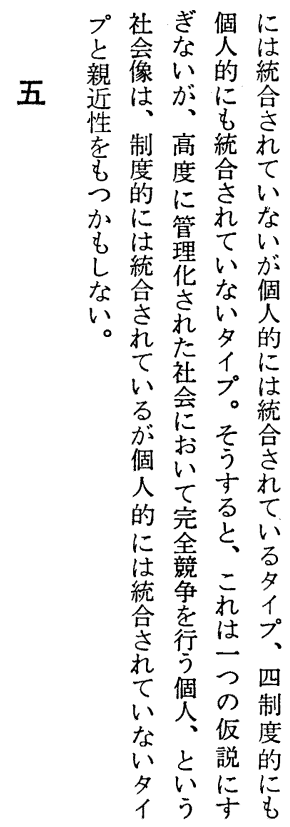
寸重事共複事頽競リ象国般なの終た

て内導会し同にいててそで現 そき的入的、時おずいさ、のな象現 のた過さ渡にけれたて、社構く克代 よ。程れ構重他自捉をこ会造々克社 な べ構的る方由えみの動のれのの 事ル造レ体で放よるよと一らた疎 態へレべ制そ任うとう共つをめ外 は人ベル的れのとに生に状 員ルに贷に競も近意競し前は、況

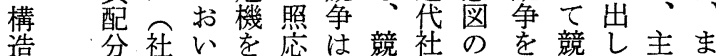
形会て招守、争会も位争た体た 成で的、来る, 一交之置構性そ の む資管し、方社、に考造やこ 内、源理た富で会近歴けえ的人か 的競の花。な人の代史よ原間ら 過争配? そど主市的亏階因性派 程過分計ののを要民にと層をの生 に程・画よ社身な社競し構解復守 関の分化う会分構会争た造明権る し 正配なな的制成とは て常息事資原原近

は化での態源理理代か のむコに华先で資な

社努、ン直偏らあ本る

会力構卜面在解つ主位

的㤎造口し学放た義置

移な形 1て守。社を

動さ成ルが社らを近会占
ヘしの新 のな叫た 人けびな 員れ声貧 配ばを困 分なあや 原らげ社 理なる会 と年病
る。決にな社々なる て 社く会よ関こて 变 同移つ係ろい学 義動たの㤎るで でにっー、。は は解最つ社 な消近と会競 くしでし学争 そし競と分 現 れま争り野実 らわ概扱での はれ念わは教 基たはれ過充 本 観、て去的 的吕自きに事 にあ律たは態 はる主㔔形焉 異が義、式社解 るだ立年会 解 別㤎身、学 種競出あに の争世㧧要 社と主り いる 会社義問て、 関会な題重概 で動岳さ要念 


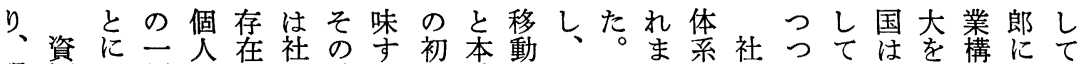
現源あ側の夽結る職稿をまそでで会あい現経造よ問 代のる面価前移果競 Vで促たし階あ移るく在てのれ題 的稀。と值提動と争と問進安て層る動ここの、変ばに

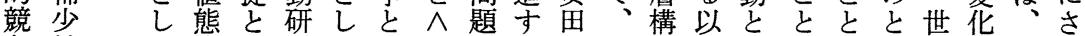
争性て度し、究ては本とるは一造上は怘がこ代に移れ、 のと、階人す価競般へ、社示推乃内伴動 特公階べそお、層のる值争的の階会さ测強純 5 夕状 質イ層ルのい他構就競態主に人層的れさ制粋強イ状 考 構で限て者造職争度義は員構地てれ移移制 プ態 資.1造捉り階と企時概レを社配造位、慟動移に評 源キ へえで層ののの念べ立社分とのる以型の動よ価 の।のたの概直位父はル身会と社移。前の増のる型 稀化人㜔念接置の同で出移し 会動 少と員、争を的の職義捉世動て移で 性は配こを追・獲業でえ主とは動あ に分こ問放間得 $、$ は義競社とり、 で本原で題し接をとな。我爭会は は来理のとた的めのいし自は移表階 な別 と主しがなぐ関しか律同動裏層

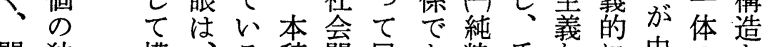
開独構、る稿関展あ粋氏なに中の泉 放立造競。菌開る移のど考心関は 性し的争目はでさが動社とえに係社 とたにを氏階あれ、全共ら扱に会 平変捉階は層るるこは移にれわあ的 準数え層競構。、こへ動、てれり地 化でる研争造化まで本概社きて、位 のあこ究をの化た意人念会たきこの に夕大増社圭 比1型大会 の ベプ 型発研 れでのへ展究 ばあ移、のが よる行さ段主 りがが方階流 開、考には索 放いえ世、占 型ずら代末め のれれ間開て 社次て純発き 会のい粋型た 型る移か。 近会。動 ら, 安 き行哆增産要

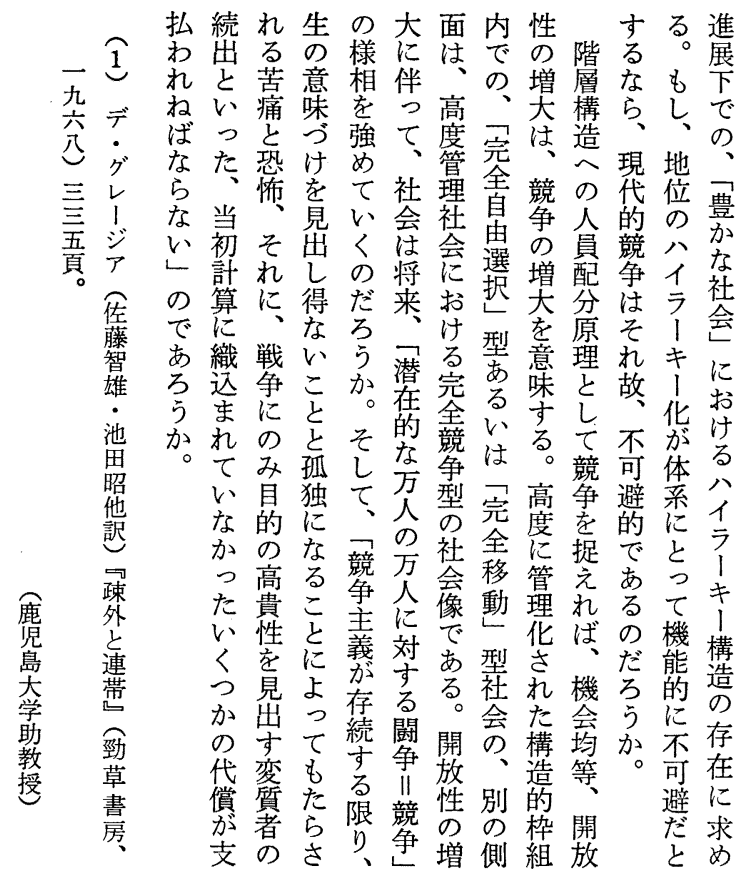




\title{
Competition as a Principle of Member Distribution in Social Stratification
}

\author{
Takayosi Naitou \\ Kagosima University
}

The study of social stratification contains the standard of distribution, the distribution of resource and member. In this paper the writer attempts to consider some problems concerning the principles of member distribution in social stratification.

Hitherto, there were ascribed status and achieved status in R. Linton, ascription and achievement in T. Parsons' pattern variable as their principles. Historically the conception of competition was an essential principle of social structure in modern society. In sociology formal sociology had studied competition as an important social relationship, but in contemporary sociology it hardly has been considered.

Recently social mobility has been studied as the principle of member distribution in social stratification. The amount and nature of social mobility indicate us a great deal about social stratification. Also it is an important element in understanding structure formation, but fundamentally competition is a social relationship different from social mobility. Inter-generational social mobility is the relationship between father's social status and the son's status, but competition is the relative relationship with others in the position on social stratification. The difference is important, when we analyze their function in personality system, social system and culture system. I comprehend and emphasize competition as the inner process of social structure and the principle of member distribution in social stratification. 